UDC 631.16:658.152

DOI: https://doi.org/10.32782/2415-8801/2019-5.24

Gutkevych Svitlana

Doctor of Economic Sciences, Professor, Head of Department of International Economics,

National University of Food Technologies

Smyk Roman

Post-Graduate, Department of Economics of Enterprise, International University of Finance

\title{
THE MAIN DIRECTIONS OF INVESTMENT ATTRACTIVENESS FORMATION IN AGRARIAN SECTOR OF ECONOMY OF UKRAINE
}

The level of investment activity is one of the general indicators of the socio-economic situation in the country. At this stage, it is crucial for the Ukrainian economy to increase production, and, consequently, to ensure the influx of investments in attractive sectors of the economy. The article aims to identify the main directions of increasing the investment attractiveness of the agricultural sector of the Ukrainian economy. Today, the investment process in Ukraine is characterized by a decrease in activity in all sectors of the economy, including in the agricultural sector. The main factors affecting the reduction in investment include a decrease in the investment attractiveness of investment objects, as well as a reduction in the sources of financing investment projects. Improving the efficiency of investment is possible only with a systematic approach to the solution of the problem.

Keywords: investment attractiveness, economy, agricultural sector, profit, factors, investment process. 


\title{
ОСНОВНІ НАПРЯМИ ФОРМУВАННЯ ІНВЕСТИЦЙНОЇ ПРИВАБЛИВОСТІ У АГРАРНОМУ СЕКТОРІ ЕКОНОМІКИ УКРАЇНИ
}

Гуткевич С.О., Смик Р.Ю.

На сучасному етапі, інвестиційний процес в Украӥні характеризується зниженням активності у всіх галузях економіки, у тому числі і в аграрному секторі. Рівень інвестиційної активності характеризує соціально-економічний стан в краӥні. На даному етапі, для економіки Украӥни важсливе значення має підйом виробництва, а отюе і збільщення забезпечення припливу інвестицій у привабливі галузі економіки. Стаття має своєю метою виявлення основних напрямів підвищення інвестиційної привабливості аграрного сектору економіки Украӥни. До основних факторів, які впливають на обсяги інвестицій, відносять інвестиційну привабливість об'єктів інвестування, джерела фінансування інвестиційних проектів та інші. Підвищення ефективності використання інвестицій можливе лише при системному підході до вирішення проблеми. На макрорівні управління інвестиційним процесом пов'язане з державним регулюванням економіки, особливо коли мова йде про активізацію інвестиційної діяльності у аграрному секторі економіки Украйни, яке вимагає системної і суттєвої підтримки держави. Дослідження джсерел самофінансування підприємтсва демонструє, щио прибуток с основним джсерелом інвестицій підприємств украӥнського аграрного сектору, а прибуток є основою ухвалення інвестиційних рішеннь. Прагнення отримати економічний прибуток - постійно діючий мотив діяльності приватного підприємця, який спонукає економіку до постійного розвитку. Рівень інвестиційної діяльності в аграрному секторі національної економіці залежить від економічних реформ, в тому числі земельної реформи та реформ в законодавчій сфері. Украӥна як об'єкт інвестування має великий науковий, людський і технологічний потенціал, багаті природні ресурси, ццо буде стимулювати процес активізації інвестицій.

Ключові слова: інвестиційна привабливість, аграрний сектор, економіка, прибуток, чинники, інвестиційний проияес.

\section{ОСНОВНЫЕ НАПРАВЛЕНИЯ ФОРМИРОВАНИЯ ИНВЕСТИЦИОННОЙ ПРИВЛЕКАТЕЛЬНОСТИ В АГРАРНОМ СЕКТОРЕ ЭКОНОМИКИ УКРАИНЫ}

\author{
Гуткевич С.А., Смык Р.Ю.
}

Уровень инвестиционной активности характеризует социально-экономическое положение в стране. На данном этапе, для экономики Украины ваэнное значение имеет подъем производства, а, следовательно, и увеличение обеспечения притока инвестиций в привлекательные отрасли экономики. Статья имеет своей целью выявление основных направлений увеличения инвестиционной привлекательности аграрного сектора экономики Украины. На современном этапе, инвестиционный процесс в Украине характеризуется снижением активности во всех отраслях экономики, в том числе и в аграрном секторе. К основным факторам, влияющих на объемы инвестиций, относят снижение инвестиционной привлекательности объектов инвестирования, а также сокрацение источников финансирования инвестиционных проектов. Повышение эффективности использования инвестиций возможно лишь при системном подходе к решению проблемы.

Ключевые слова: инвестиционная привлекательность, аграрный сектор, экономика, прибыль, факторы, инвестиционный проиесс.

Introduction. Investment activity is one of the universal characteristics of the socio-economic situation in Ukraine. For the country's economy, the rise in production and increase of investments in national attractive industries is crucial.

Recent research. Despite numerous economic studies, the problem of investment attractiveness formation as the basis for the development of the investment process has not found enough coverage in the national and foreign and literature. From the perspective of state policy approach in terms of economic development of the country, the need for further research, elaboration and introduction of new theoretical and methodological bases for the development of the investment process, market forms and mechanisms of investment attractiveness at the micro and macro levels in order to identify the most effective directions of capital investment are gaining new momentum.

Still there are not enough scientific research papers to comprehensively address the problem of investment attractiveness and the criteria of analysis of the factors and assessment of the agrarian sector in the face of global transformations in Ukraine. Therefore, the system of investment attractiveness formation requires comprehensive scientific scrutiny, which determines the topic of the article, its purpose and objectives.

Purpose. The purpose of the article is to identify the main factors of increasing investment attractiveness of the agricultural sector in Ukraine.

Results. The dynamics of the investment process in Ukraine is characterized by a decrease in investment activity and investment demand. The main factors limiting the volume of investments are the worsening of the investment attractiveness of investment objects and the reduction of the sources of their financing.

The investment demand of profitable enterprises is limited by low profit margins, high taxation, rising debt and non-payments. Forming investment attractiveness is a part of the investment process management system that brings together many elements closely related to one another, forming a certain order, integrity and unity. Like any process, investment includes a managerial dimension and is executed through functions, which are subject to certain laws and principles.

At the current stage of economic development, it is necessary to control and coordinate investment activity, 
determining the directions of investments, as well as efficiency and validity of their use.

The categories that characterize the investment process include: subjects and objects of investment, forms and sources of investment, investment capacity, infrastructure, priorities, efficiency, profits, organization, personnel, functions and a number of other economic categories related to the issues of management. Market investment policy leads to a reduction in investment in traditional areas of the planned economy, while investment in the development of private sector contributes to the investment attractiveness of domestic industries and enterprises. For example, the changes made in agriculture related to the reform of ownership, restructuring of agricultural enterprises, the formation of market relations have not led to changes in the management system. Therefore, the agrarian sector is not yet sufficiently attractive for investments.

The investment attractiveness is related, first of all, to the sources of investments and conditions that allow to provide investments to producers. There exist a few sources of investment in an object. Each of them has its own peculiarities of formation, as well as regulatory and legal conditions for their receipt and implementation.

Improving investment efficiency is only possible with a systematic approach to problem solving. As it was already noted, at the macro level the management of the investment process is connected with the state regulation of the economy, because for Ukrainian agriculture the activation of investment activity requires the support of the state.

Currently, the amount of budget funds in the total amount of investments has decreased, the state is no longer the main executor of the investment process, but rather performs an indirect influence on the market through the system of taxes, credits, depreciation, benefits, subsidies etc.

Under market conditions, state investments, as a source of investment, should be channeled into priority industries and sectors. For example, the development of the agricultural sector of the economy: chemical soil reclamation, support for industries with export potential, as well as the development of social sphere and infrastructure, which provides the conditions for the development of production.

Investments in highly profitable industries generates revenues, as these industries are efficient, knowledge-intensive and provide for the process of expanded reproduction, their products are competitive, and this contributes to the economic and social development of the country.

One of the components of successful reforms in modern countries is the development of scientific, technical and humanitarian potential, in particular its intellectual component. Scientific and technological progress is becoming increasingly financially-intensive. Financial resources are needed for Ukraine - investments in any form.

Investing in the social sphere is conditioned by the qualitative improvement of the organization of production, which is carried out on an innovative basis, which will stimulate the investment attractiveness of the industries. The social assessment of investment performance depends and is determined by a system of indicators of quality of life.

One of the defining conceptual methodological aspects of socio-economic reform in Ukraine is the solution of the question of the interrelations of the interests of man, society and the state. In practice, this means that the priority should be given to the interests of man as the main object of investment, while the interests of the state should be derived from the interests of man, stabilizing its political and economic position, since the socio-economic situation affects the flow of investment into the country. When making an investment decision, a hierarchical scheme is studied that characterizes the basis of the vital values of man and society and shapes the image of the country.

In the world, information and knowledge are becoming a strategically important commodity, which is why investments are reoriented, primarily switching the investment of capital into human resources. The state of the national economy and the well-being of citizens are determined and dependent on the policies of state bodies.

The function of the state and the condition that provides for the increase of investments in production is the creation of social goods: national security, education, environment, health care, creativity etc.

Budget deficits make it difficult to obtain public loans, so the share of the state in the process of investment and state's guarantees to private loans are more preferred. According to foreign economists, who analyze the economic condition of our country, government investment should not be associated with supporting unprofitable production and increasing taxes.

Intensive investment, in contrast to extensive one, provides for additional profits while improving the quality of investment use. The increase in capital should be optimized taking into account the marginal efficiency of investment.

The main purpose of the investor is to earn profit. The amount of profit can be expressed as a percentage of investment costs, called the return on investment or the profitability level.

However, there is a general pattern - as investment increases, profitability decreases. Thus, the marginal efficiency of investments depends on the level of profitability, volume of investments and quality of their use. There is a relation: when the volume of investment increases, the profitability or the amount of income decreases. This is explained by the effect of economic laws. Any company has the opportunity to obtain certain benefits from investment activities that are to increase profits.

In the investment process, it is not the amount of profit that matters to the investor, but the part that remains at his or her disposal, since it is a source of self-financing. Based on the study of the flow of capital flows, based on the strategy of regional policy, the algorithm of financing or investing in an object, which can be any enterprise or organization, is proposed.

Effectively operating enterprises have the opportunity to independently form sources of their own investment, including, first of all, the profit remaining at the disposal of the enterprise, depreciation funds, reserves. The rational use of sources of investment contributes to the effect and is a factor affecting investment attractiveness and priority.

Research on sources of self-financing of the enterprise allows to define profit as the main source of investment of the enterprise. Profit is the basis for making an investment decision and should considered from two positions:

- first, as the profit received from the production and sale of products (services);

- secondly, as the profit in the form of interest (dividends) received from the acquisition of securities;

Profitability, as an indicator that allows to predict the level of profit of an enterprise, is evaluated in monetary 
terms, taking into account various factors: the ability to successfully negotiate credit terms, market position, technology, quality of management, increase in the face value of the enterprise. Profit is a reward for the investment risk.

Innovation as an object of investment and a process of constant renewal includes all changes that help to improve the activity of an enterprise while controlling the profitability of all activities. The innovation process contributes to improving the efficiency of the economy and working conditions of human resources.

In the process of successful innovation, profit growth is ensured mainly through:

- release of new products;

- creation of new markets;

- labor productivity growth;

- use of new raw materials.

At the macro level, the formation of national innovation systems is needed to stimulate the development of innovation.

The factor affecting profit is the size of an enterprise. Large enterprises have a higher technical and economic level, which ensures high productivity and return.

In countries with a market economy, there is a direct correlation between the size of an enterprise and the reduction of risks and the likelihood of bankruptcy. At the regional level, large enterprises are more competitive, able to diversify production and influence the markets. But the factor of increasing the size of the enterprise has a definite purpose, as well as a tendency to stabilize profit growth or decrease it depending on the industry.

Let us consider the factor relationship between the profit and the market. Given that investors prefer the most profitable assets or investment goods with the highest rate of return on invested capital, an enterprise should strive to effectively use its competitive advantages, which will provide it with economic stability in market volatile relationships and income generation.

Estimated or projected (expected) profit is established as a basis for taxation. The expected level of return on investment contributes to their increase and, conversely, decreases in return on investment leads to the fall in demand for investment goods. An alternative to direct investment is a bank deposit that allows to obtain an interest rate.

Under modern conditions, financial markets use savings to generate new capital and increase profits. Profit is influenced by inflation, which reflects an increase in the average price level in the economy and allows enterprises to hide real productive data of their activities, making a significant impact on the profit generated. Without government regulating inflation rates, profit becomes a mechanism for redistributing depositors' and taxpayers' funds to merchants and bankers. Factors that shape profit, cause it to perform a number of functions that influence the investment process.

The desire to earn economic profit is a constant motive that drives the economy to continuous development.

Based on the calculation of expected and received profits, the following profit functions can be distinguished:

- planning. For the expected profit is the basis for making an investment decision;

- development. For the profit determines the success of the enterprise;

- self-financing. The earned profit is a source of financing for development or reproduction;
- stimulus, which characterize the return on investment associated with the receipt of part of the profits as a reward to the owners of capital (entrepreneurs).

These features can be considered classic for the market. The first two functions are interdependent, because the former is meaningful only if the second holds true, the third function promotes production. The fourth function involves a partial solution to the problem of profit allocation and production expansion.

These functions are directly related to the problem of enterprise development and investment decisions. The role of profit in making an investment decision depends on its type: short-term expected profit is complete self-financing, which implies rapid investment. Investment costs allow to expand the activities of the enterprise and are invested in buildings, facilities, machinery, equipment and etc.

Basically the process involves long-term investments, so the next type of profit is the long-term expected profit. It is related to the production cycle. Profits expected over a number of years are measured in the same units, that is, are reduced to a settlement period or discounted. In developed countries, the only possible criterion for the direction of investment processes is to obtain maximum profit (in the short, medium and long term).

In the public sector, the criteria for investment decisions are based on either the criteria of overall profit or profit of the producer. Any economic sphere or economic system cannot exist without the criterion that determines the distribution of investment between industries and enterprises. The investment process should not be limited to forecasting profit, because it is necessary to manage the process of obtaining it.

The source of investment for businesses is loans from commercial banks and other financial institutions. This source characterizes the activity of domestic potential investors and the level of lending to the national economy by the commercial banks. Solvency means the ability of an enterprise to comply with the conditions under which loans were granted.

The volume of the loans of commercial banks depends on the level of interest. If the price of the loan exceeds the financial efficiency of production (its profitability), there are no financial guarantees for the loan repayment. Banking capital, given the volatility of the economic sectors, is channeled mainly into selected highly efficient industries. Long-term loans in the form of investment leasing can be used for investment purposes. Leasing agreements are most beneficial to banks and financial companies because they have a collatersl - the object of leasing. Leasing involves both a sales and lease relationships, and is based on a loan agreement between the bank (leasing company) and the lessee.

Investment leasing benefits agricultural producers who do not have new technical equipment or equipment that can be rented for seasonal work. Stimulating investment leasing involves providing a variety of benefits in regions and industries, especially with low technical equipment that produces complex technical products, raw materials and food.

A private investor can be any citizen of the country with free funds. In developed countries, this source is of great economic importance. The task of the state in the sphere of investments is to develop a motivational mechanism that contributes to attracting funds from the population in the investment process, improving their efficiency. 
Research into the sources of investment in enterprises has shown self-financing to be the primary element in the process of making an investment decision. Important factors for making an investment decision are: investment attractiveness and priority; voluntary investment, that is, the investor's independent choice of the object of investment; the amount of revenue generated depending on the risk; economic efficiency of the investments, which depends on the interest in the results of the investment activity of the "subject" and "object" of the process. One of the most important conditions for managing the investment process is planning or forecasting capital gains - profits. Depending on the economic and political system, the benchmark of investment decisions and a measure of the effectiveness of managing the investment process may be profit.

Based on the study and generalization of the development of the investment process, the model of formation of the investment system at the present stage of development is proposed, which includes the following stages and levels:

- the first stage is the investment of capital in the objects of investment, which are profitable, taking into account the conditions and factors of priority, attractiveness and profitability of both regions and individual enterprises;

- the second stage specifies the task of the first level: investing in order to stir up the activity of enterprises and eliminate the causes of production decline by obtaining and using their own sources of investment;

- the third stage determines the need to manage the investment process, based on the purpose of investing income (profit), as the main source of development of any enterprise.
The investment system is formed taking into account the forms of investment, sources and directions of investment. Investment attractiveness as a condition of investment ensures the inflow of investments into the fixed capital of enterprises, the volume of which depends on the scale of production of the investment object. Governance at the regional level is associated with the intensification of investment activity in the implementation of regional economic reforms based on the redistribution of powers of the center and regions and the gradual expansion of the rights of regional governing bodies.

It is the investment attractiveness of regional development programs, such as industries, associations, that will intensify national regional policy.

Conclusion. The level of national investment activity is related to economic reforms in the fields of economy, land and legislative reforms, as well as the state regulation of the investment process.

The investment system at all levels should include and combine possible sources of investment in production, giving priority to the internal resources of the economic entity, which will positively effect the efficiency of the investment process, enhance the welfare of society and ensure its development in the future on the basis of vital values.

Our country has great scientific, human and technological potential, rich natural resources. The efficient use of this potential would be possible provided that investments are attracted from both foreign and domestic investors. Reforming Ukrainian economy on the basis of the combination of domestic and foreign capital meets the national interests of Ukraine and makes it more attractive to investors.

1. Gutkevych S.O. (2019). Investment attractiveness of industries: features and trends. Baltic Journal of Economic Sciences. Vol. 5, No. 3. doi: 10.30525/2256-0742/2019-5-3-50-58

2. Gutkevych S.O., Sydorenko P.O., Veklych V.O. ta inshi. (2016). Teoretychni zasady pravovoho rehuliuvannia investytsiinoi diialnosti. Kyiv : NUKhT.

3. Markevych K., Yurchyshyn V. (2014). Priorytet investytsiinoi pryvablyvosti v politytsi stiikoho ekonomichnoho zrostannia Velykoi Brytanii Mizhnarodna ekonomichna polityka. URL: http://nbuv.gov.ua/UJRN/Mep_2014_2_5

4. Pro investytsiinu diialnist: Zakon Ukrainy vid 18.09.1991 r. Zakony Ukrainy: U 12 t. T.2. Kyiv, 1997. S. $173-180$.

5. Pro rezhym inozemnoho investuvannia: Dekret KMU vid 20.05.1993 r.

6. Pro rezhym inozemnoho investuvannia: Zakon Ukrainy vid 19.03.1996 r. Uriadovyi kurier. 1996. 25 kvitnia.

7. Formuvannia hlobalnoho i rehionalnoho rynkiv silskohospodarskoi syrovyny i prodovolstva: monohrafiia (2015); za red. Yu.O. Lupenka, M.I. Puhachova. Kyiv : NNTs «IAE».

1. Gutkevych S.O. (2019). Investment attractiveness of industries: features and trends. Baltic Journal of Economic Sciences. Vol. 5, No. 3. doi: 10.30525/2256-0742/2019-5-3-50-58

2. Гуткевич С.О., Сидоренко П.О., Веклич В.О. та інші. Теоретичні засади правового регулювання інвестииійної діяльності. Київ : НУХТ, 2016.

3. Маркевич К., Юрчишин В. Пріоритет інвестиційної привабливості в політиці стійкого економічного зростання Великої Британії Міжнародна економічна політика. 2014. № 2. URL: http://nbuv.gov.ua/UJRN/ Mep_2014_2_5

4. Про інвестииійнудіяльність: Закон Украйни від 18.09.1991 р. Закони України: У 12 m. Т.2. К, 1997. С. $173-180$.

5. Про режим іноземного інвестування: Декрет КМУ від 20.05.1993 р.

6. Про режим іноземного інвестування: Закон Украӥни від 19.03.1996 р. Урядовий кур'єр. 1996. 25 квітня.

7. Формування глобального $i$ регіонального ринків сільськогосподарської сировини $i$ продовольства : монографія; за ред. Ю.О. Лупенка, М.І. Пугачова. Київ: ННЦ «ІАЕ», 2015.

E-mail: r.s.uawriters@gmail.com 